\author{
MOLNÁR DÁVID
}

\title{
A Katolikus Egyház és a korai munkásmozgalom kapcsolata Egerben 1890 és 1914 között
}

\section{Eger a 19. és 20. század fordulóján}

A Bükk-hegység lábánál fekvő Eger városa a magyar történelem egyik kiemelkedő színtere, melynek belső életén, társadalmi és gazdasági viszonyain a 19. században zajló modernizációs folyamatok is nyomot hagytak. Az 1867-es közjogi kiegyezést követően a város népességszámának lassú emelkedése tovább folytatódott. A dualizmus utolsó évtizedeiben a városi lakosság közel negyedével gyarapodott, mely átlagosan 0,75\%-os népességnövekedést jelent a tíz évente megtartott népszámlálási adatok tükrében. ${ }^{1} \mathrm{~A}$ növekedési tendencia példátlan a város ezeréves történetében, azonban más városok dualizmus idején tapasztalt fejlődésének fényében egyáltalán nem kimagasló. ${ }^{2} \mathrm{Az}$ egri népesség dualizmuskori gyarapodása nagyjából az országos tendenciával egyenlő mértékü. A többi vidéki városhoz való lemaradás hátterében a demográfiai tendenciák megváltozásán és a járványok pusztításán túl a város kedvezőtlen közlekedés földrajzi elhelyezkedése sejthető. ${ }^{3}$ Ugyan 1873-től a születések számának növekedése figyelhető meg, a halálozási arány továbbra is magas maradt, mely 50\%-ban az 5 éven aluli gyermekeket érintette, és a lakosságnak csupán 15\%-a élte meg 60. életévét. Az Egerbe irányuló migráció ugyan hatással volt a népesség számának alakulására, és a helyi társadalom belső viszonyaira, azonban a dualizmus második felére Eger az oktatási, egyházi életben betöltött szerepét leszámítva elvesztette centrum jellegét. ${ }^{4}$

\footnotetext{
A Magyar korona országaiban 1891. év elején végrehajtott népszámlálás eredményei. I. rész. 142. ill. A Magyar Szentkorona Országainak 1900. évi népszámlálása. I. rész. 532. Illetve A Magyar Szentkorona Országainak 1910. évi népszámlálása. I. rész. 803. (továbbiakban: MSO 1891/1; MSO 1900/1 ill. MSO 1910/1.)

2 Míg az egrihez a 19. század első felében hasonló lakosságszámmal és városias jelleggel bíró Kassán a népesség megduplázódott (1910-re 44.200fö), addig a közeli Miskolcon háromszor annyian éltek a történelmi Magyarország utolsó népszámlálásakor, mint Egerben. Veres 2011: 101- 105.

3 Uo., ill. Csesznokné 2007: 260- 261.

4 Demeter 2007: 2.
} 
A városhierarchiában bekövetkezendő presztízsvesztést csak súlyosbították a természeti csapások nyomán fellépő gazdasági válságok. Az 1873-as árvíz következtében jelentősen megrongálódtak a külvárosi földművesek ingatlanjai, csak úgy mint a belvárosban található kiskereskedések, műhelyek, üzletek, valamint a világi és egyházi reprezentatív épületek. ${ }^{5}$ Alig tizenöt évvel később a városi lakosság jelentős részének megélhetését biztosító szőlőtermelés került nehéz helyzetbe azáltal, hogy a filoxéra járvány az Eger környéki szőlők több mint 90\%-át elpusztította. ${ }^{6}$ A környezeti-gazdasági katasztrófát követő szociális válság a századforduló éveire érte el mélypontját, ${ }^{7}$ és ez megnyilvánult a helyi társadalom foglalkoztatás-statisztikai jellemzőiben is.

A szőlővel rendelkező birtokosok megélhetésük forrásától estek el, csakúgy mint a bérmunkát vállaló paraszti réteg, aminek következtében az őstermelésből élők aránya 1900-ra a város keresőinek 28,5\%-ra, míg 1910-re 27\%-ra csökkent. ${ }^{8}$ A kereskedelemben, közlekedésben és iparban 1892-ben összesen 3727 fö dolgozott, mely az összlakosság 16\%-át alkotta. A következő húsz évben arányuk, a népesség növekedésével párhuzamosan, 18\%-ra nőtt az összlakosságon belül, míg 1910-ben már a kereső népesség 38\%-át alkották. ${ }^{9}$ Jelentősnek mondható továbbá a házi cselédek aránya, akik a keresők 10-12\%-át tették ki a huszadik század hajnalán, valamint a keresők átlagosan 8\%-át jelentő értelmiségi és hivatalnokréteg, továbbá a több mint ezer fös katonai helyőrség. ${ }^{10}$

Foglalkozás-statisztikai tulajdonságaival szemben a város etnikai és vallási tekintetben meglehetősen homogén képet mutatott a századfordulón. Egy pár száz fös kisebbséget leszámítva szinte mindenki magyar anyanyelvünek vallotta magát a népszámlálási adatok felvételekor, a helyiek identitásának pedig szerves része volt a '48-as függetlenségi hagyomány ápolása. Az egriek átlagosan 85\%-a katolikus, míg 3\%uk valamely protestáns felekezet tagja volt. A városban megtalálható három izraelita hitközség a lakosság 10-11\%-át gyüjtötte össze, míg arányuk országos tekintetben átlagosan $5 \%$ körül mozgott. ${ }^{11}$

A 19. század végén és a 20. század elején Eger társadalma változáson ment keresztül. A legszegényebbek igyekeztek élni a társadalmi mobilitás kínálta szűkös lehetőségekkel, vagy a ki-, illetve elvándorlást választották. A helyi elit sikeresen őrizte pozícióját, azonban a középrétegek egy jelentős részének megélhetési és érvényesülési nehézségekkel kellett szembenéznie. Közéjük tartoztak a helyi kisiparosok, kisbirtokosok, üzemi munkások és kiskereskedők, valamint az értelmiség egyes tagjai. Bár a középosztályt alkotó társadalmi csoportok meglehetősen sok szempont szerint

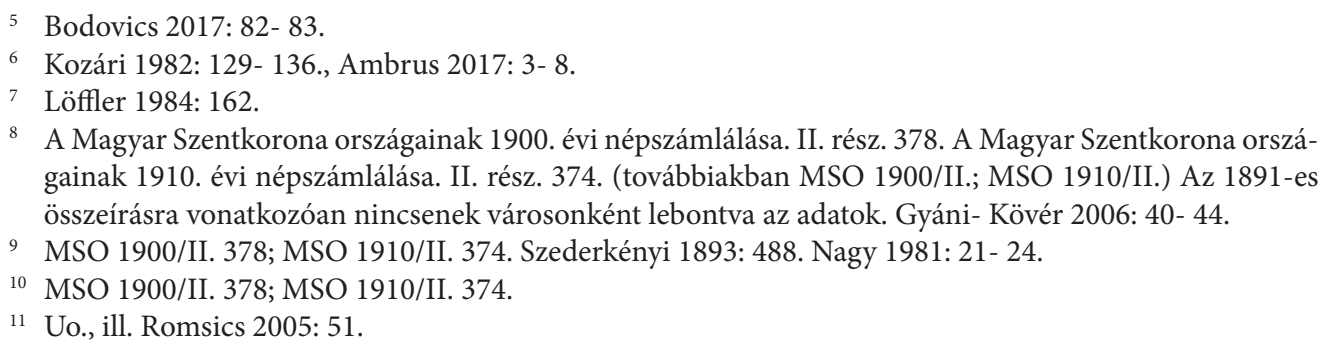


rétegződtek, életmódjukban és mentalitásukban egyaránt a kispolgári jellemzőket fedezhetjük fel. ${ }^{12}$ A polgári életmódhoz való ragaszkodás (tulajdonhoz való jog, írásolvasás, közügyekben való részvétel stb.) mellett, a bizonytalan gazdasági körülmények miatt az egri középosztály egyes csoportjai fogékonnyá váltak a 19. század második felében megjelenő új ideológiák iránt is. A tőkés viszonyok átrendeződésével, és a modern kapitalista gazdaság helyi kialakulásával egy időben egyre többen értesültek, és kezdtek kisebb-nagyobb szimpátiával, vagy épp ellenszenvvel, viseltetni a korban újnak számító szocialista ideológiák iránt.

\section{A katolikus egyház társadalomszervező tevékenysége Egerben a munkásmozgalom korai időszakában}

Bár Heves vármegye nem volt híján nyersanyaglelöhelyeknek, az erre épülő feldolgozóipar mégsem virágzott fel, köszönhetően annak, hogy a 19. században zajló vasút- és közlekedésfejlesztés nyomán létrejövő útvonalak elkerülték a megye nagyobb városait, így Egert is. ${ }^{13} \mathrm{~A}$ megye lakosságának jelentős része továbbra is az agráriumban tevékenykedett, azonban a jobbágyfelszabadítás után immár igazodnia kellett a mezőgazdaságban is kialakuló tőkés viszonyokhoz. A paraszti termelés egyik speciális fajtája volt Eger környékén a dohánytermesztés, melyet idővel a vármegye müvelésre alkalmas területeinek 2/3-át kitevő nagybirtokok is kezdtek részben átvenni. ${ }^{14}$ Ennek köszönhetően a filoxéra-válság mélypontján, 1895-ben nyitotta meg kapuit az Egri Dohánygyár a vármegye központjában, mely a századfordulót követően a helyi iparban dolgozók több mint 20\%-át foglalkoztatta, azonban a gyár dolgozóira egy-két kivételt leszámítva nem volt jellemző az aktív önszerveződés a korszakban. ${ }^{15}$ Ilyen előzmények után, és látva a gyáripar gyengeségét, megkérdőjelezhető, hogy az 1945 után született történeti irodalomban nagy hangsúlyt kapó, és a gyáripar dolgozóit tömörítő munkásmozgalom egyáltalán releváns tényezőnek számított e Eger késő dualizmuskori történetében.

A mozgalom csíráit Egerben nem a nemlétező modern ipari proletariátusban, és nem is a legszegényebb parasztok soraiban, hanem a már említett középosztály csoportjai között kell keresnünk. A kiegyezést követően a fövárosban, mint az ország

12 A középosztály és a kispolgárság problematikájáról bővebben: Szokol 2011: 104- 105. Gyáni- Kövér 2006: 186- 194.

${ }_{13}$ Misóczki 2001: 235- 238.

${ }^{14}$ A Heves vármegyében található művelésre alkalmas 651642 holdnyi földterületből 404511 holdon 550 család gazdálkodott. Eger, 1893. szeptember 19. 301. Nagy 1981: 16- 28.

15 1901-ben 670; 1910-ben pedig 780 alkalmazottal az iparban dolgozó kereső népesség 23, illetve 21\%-át alkották. Csóka 1958: 379. MSO 1900/II. 378; MSO 1910/II. 374. 
egyik legiparosodottabb központjában jöttek létre az első munkás egyesületek, melyek élén többnyire erős külföldi (főleg német) gyökerekkel és kapcsolatokkal rendelkező, szakképzett, és a nemzetközi mozgalmak példájából merítkező munkások álltak. A termelésben betöltött kivételes szerepük miatt jogosnak érzett követeléseik két csoportba oszthatók: gazdasági követeléseik a munkavégzés körülményeinek javítására (nyolcórás munkanap, gyermekmunka eltörlése, beteg- és balesetbiztosítás stb.) irányultak, míg politikai szempontból a választójog kiszélesítése és egy párt alapítása révén szerettek volna bele szólni az ország közügyeibe. ${ }^{16}$ Nézeteik és követeléseik terjesztésének érdekében újságokat hoztak létre. Ennek köszönhetően hálózatszerüen kapcsolatba kerültek a vidéki városok dolgozóival, így az egri származású Szabó Sándorral is.

A szabó foglalkozású Szabó életéről nem sokat tudunk. A Nemválasztók Pártjának 1878. áprilisi alakulógyülésén a kongresszus elnökségi tagjává, két évvel később pedig (a már említett pártból kiváló Külföldi Viktor vezette frakcióval való újraegyesüléskor) a Magyarországi Általános Munkáspárt alakuló ülésének jegyzőjévé választották. ${ }^{17}$ Ezzel egyidőben élénk levelezésben állt a Munkás-Heti Krónika, majd a Népszava szerkesztőségével, akik többek között a kortárs szocialista irodalom egyes darabjait is eljutatták hozzá Egerbe. ${ }^{18}$ A helyi szakmai szerveződésekben is igen aktív Szabó élénk figyelemmel kísérte a hazai és nemzetközi politikai eseményeket. Több polemikus hangvételü írást küldött a munkásújság szerkesztőinek, melyekben egyes cikkek tartalmával és azok íróival vitatkozott, meglehetősen zavaros és pongyola stílusban. ${ }^{19}$ A szerkesztőség idővel arra kérte Szabót, hogy az elméleti fejtegetések és vitázás helyett inkább az egri munkásokat érintő legfontosabb eseményekről tudósítson. ${ }^{20}$

A Magyarországi Általános Munkáspártot az I. Internacionálé és a gothai program irányvonalait követve kezdetben egy politikailag aktív szociáldemokrata pártként képzelték el alapítói. Alig egy évvel később a párt meghatározó vezetőjét, Frankel Leót

${ }^{16}$ A szocialista jellegủ munkásmozgalom kezdeteit az Általános Munkásegylet 1868-as megalapításától számíthatjuk, mely a Ferdinand Lassale-féle „államsegély” programját támogatta, miszerint a munkások helyzetének javítását az államilag segélyezett termelőszövetkezetek révén kell megoldani. Kozári 1999: 22- 26.

17 A magyar munkásmozgalom történetének válogatott dokumentumai I. 327, 385.

${ }_{18}$ Népszava, 1880. április 11. 22. A szerkesztői üzenetek között olvashatjuk, hogy az angol és francia nyelvủ újságokat már postára adták Szabó részére. Pár hónappal később a rendőrség házkutatást tartott nála, miután a Népszaván keresztül országos gyüjtést szervezett az egri árvízkárosultak javára, és mely során saját elmondása szerint „... 8 darab alapszabály a munkások nemzetközi egyesületétől, 40 darab Anti-Syllabus, felhivás a nemválasztók kongresszusától, magyar és német munkásnaptárok, a nálam talált összes magyar és német munkáslapok, egy csomóba irományok, melyek az egri árviz alkalmával különféle helyről bejött levelek, aláírási ívek, számlák, nyugták és idevonatkozó mindenféle iratok." lettek lefoglalva. Népszava, 1880. július 11. 48.

19 Munkás-Heti Krónika 1879. június 1. 4. „Szerkesztői üzenet” alatt „Tárgyilagosabban tartva és olvashatóbban, nagyobb gondossággal és nem annyira pongyolán írva szívesen helyet adnók annak (mármint Szabó cikkének- M.D.)."

${ }^{20}$ Népszava, 1880. június 27. 44. Szerkesztői üzenetek rovatban olvasható: „Közöljük (mármint Szabó egyik írását -M.D.), ámbár közvetett polemizálást nem szívesen veszünk, inkább vidéki értesítéseket vagy önálló fejtegetéseket kérünk." 
bebörtönözték, az új vezetésre pedig a politikai követelések helyett a gazdasági jogok iránti törekvés lett jellemzö. ${ }^{21} 1887$-ig ezért nem is találkozunk Szabóval a forrásokban, ekkor azonban politikai szervezőmunkába kezdett. November 13-án a Szabó által rendezett „választójogi naggyülés” elnökének választotta meg a Függetlenségi Párt veteránjának számító Csiky Sándort, Eger képviselőjét, valamint követelte az általános, titkos és egyenlő választójogot. Két évvel később újabb, Szabó által szervezett gyülésre került sor, melyen szintén zömében helyi kisiparosok vettek részt, és a választójog kiterjesztésén túl követelték a vasárnapi munkaszünet bevezetését, továbbá hogy vagyonuk 300 forintig bírói ítélet által ne legyen lefoglalható. ${ }^{22}$ Mindemellett értesülve a II. Internacionálé felhívásáról, határozatot hoztak 1890. május 1-jének díszes megünnepléséről. ${ }^{23}$

Május elsejéket 1890-ben és '91-ben is tartottak Egerben, valamint Szabó részt vett a Magyarországi Szociáldemokrata Párt 1890. decemberi alakuló ülésén, az ott megfogalmazott elvi nyilatkozat vitájához többször is hozzászólt. ${ }^{24} \mathrm{Az}$ ígéretes kezdet után az egri szocialista/szociáldemokrata jellegű szervezkedés átmenetileg megrekedt, azonban tény, hogy a május 1-jén, és más nagygyüléseken megjelent, a gazdasági viszonyok, valamint a dualista rendszer válságának mélyülése miatt ${ }^{25}$ frusztrált helyi kisiparosok reprezentálták erejüket, mely a város hagyományos hatalmi elitjét is cselekvésre késztette.

A város hatalmi piramisának csúcsán az egri érsek sokáig mint a város földesura foglalt helyet. A szabadságharc leverését követően 1854-ben, igazodva az áprilisi törvények szelleméhez, végül lemondott e jogáról, azonban a város gazdasági, politikai, kulturális és közösségi életében a katolikus egyház továbbra is aktívan jelen volt. Gazdasági-társadalmi szempontból fontos tényező volt, hogy az Eger és környékén található önálló birtokok mintegy 23\%-a az egyház tulajdonát képezte (vagy volt annak haszonbérlője), az uradalmi cselédeknek pedig közel 80\%-át foglalkoztatta

21 Kozári 1999: 31- 32.

22 E legutóbbi követelésük mutatja, hogy a nehéz gazdasági helyzet és a középosztály elszegényedése során egyre gyakoribbá váltak a lefoglalások és elárverezések.

23 1886. május 4-én a munkaidő rövidítéséért szervezett chicagoi tüntetésen anarchisták bombát robbantottak a tömeg soraiban, azt követően pedig dulakodás és tűzharc vette kezdetét a rendörök és tüntetők között, aminek következtében nyolcan meghaltak és többeket bebörtönöztek. A három évvel később, Engels vezetésével összeülő második Internacionálé ezért az elhunytak emlékére valamennyi ország munkásszervezeteit felszólított, hogy a május elsejéket tömegrendezvények keretein belül ünnepeljék meg. http://ujkor.hu/content/tavaszi-viragzastol-a-munkasunnepig-majus-1-e-jelentesvaltozasanaktortenete(Letöltve: 2020.05 .29 .)

24 A párt nevéről szóló vitában első hozzászólóként fejtette ki többek között, hogy a „...munkáspárt név sokakat zavarba ejt” ezért azt ajánlja, hogy az új párt vegye fel a „Magyarországi Szociáldemokrata Munkáspárt” nevet. A magyar munkásmozgalom történetének válogatott dokumentumai II. 42- 48.

25 E válság okait Hanák Péter nyomán a multietnikus monarchia nemzetiségi problémáinak helytelen kezelésében, a dualista rendszer intézményi felépítése és az annak fenntartása érdekében alkalmazott nem megfelelő kormányzati politikában, valamint a kapitalista gazdasági viszonyokra való nem megfelelő társadalmi reakciókban lehet meghatározni. Hanák 1959: 78- 86. 
ezeken. ${ }^{26}$ Hatalmi-politikai szempontból a liberális egyházpolitikából adódóan az egész dualizmus korára vonatkozóan egyfajta folyamatos presztízsvesztés figyelhető meg, azonban az 1871-ben bevezetett virilista rendszer következtében 1914-ig átlagosan 3-4\%-ban egyházi személy is jelen volt az egri képviselőtestületben, mint a legtöbbet adózó káptalan vagy egyes plébániák képviselöje. ${ }^{27} \mathrm{~A}$ város hétköznapi életében pedig, mint az iskolaváros oktatási intézményeinek fenntartója, valamint a korszakban gombamód szaporodó egyesületek pártfogója volt jelen. A polgárságot összefogó városi kaszinókon kívül az 1860-as évektől aktívan közrejátszott a helyi alsó-középosztály felkarolásában, de legalább ennyire meghatározó volt a papság tudományos, valamint közéletei tevékenysége is.

A helyi érdekképviselet ellenére a 19. század végére az egyháznak, így az egri érseknek is szembe kellett néznie a kormányzat liberális egyházpolitikájával, mely kétségkívül felgyorsította a szekularizációt, valamint az egyház társadalomra és politikára vonatkozó befolyásának csökkenését. Ebben a folyamatban különösen nagy szerep hárult Samassa József egri érsekre, ki az állam és egyház közötti közvetítés által igyekezett a katolikus felső papság érdekeit (is) védeni. ${ }^{28}$ A nyilvánosság előtt pedig az egyre fenyegetőbbé váló kultúrharcot több esetben az idegen, modern eszmék káros hatásaival magyarázta, ${ }^{29}$ így az irányítása alatt álló, és elméleti vagy épp irodalmi tevékenységet folytató papság számára program lett, a liberalizmuson túl, a szocializmushoz tartozó elvek vallási alapon történő megcáfolása is a hívők felé.

A 19. század második felében a nyomdaipar fejlődése, az analfabetizmus csökkenése, valamint a nyilvánosság kiszélesedése miatt elterjedő hírlapokra az egyház is hasznos eszközként tekintett a tömegkommunikáció szempontjából. A Szentszék részéről meginduló modernitásellenes mozgalom retorikájával a hazai katolikus sajtó (már jóval az egyházpolitikai reformok körüli harc kezdete előtt) is hamar azonosult. Bár országos katolikus lapnak nem sikerült akkora népszerüségre szert tenni, mint egyes polgári médiumoknak, az Egerben megjelenő helyi érdekeltségü újságok végig tükrözték az egyház befolyását. Ilyen volt az 1863-ban még liberálisabb hangvételü Eger címü egyház-közeli regionális lap, az 1869-től 1893-ig Luga László által szerkesztett egri Népújság, majd szintén az általa gondozott (bár politikailag már sokkal szókimondóbb) Egri Híradó, illetve az egri egyházmegye félhivatalos lapjának tekinthető Egri Egyházmegyei Közlöny. Ez utóbbi '69-es megalakulását követően létrehozták a papság sajtó és irodalmi munkáinak kiadására szolgáló Irodalmi Egyesületet is, mely nem sokkal később Népkönyvtár sorozat kiadásába kezdett. ${ }^{30}$

\footnotetext{
26 A magyar korona országainak mezőgazdasági statisztikája I. 1897: 290. Magyarországi Gazdaczímtár 1911: 296.

27 A törvény értelmében az önkormányzatok képviselőinek felét az adott település legtöbbet adózó személyei és intézményei alkották. Gyáni- Kövér 2006: 72- 74., Nagy 1978: 290. Eger, 1914.március 4. 2.

28 Kárbin 2018: 153- 159.

29 Egri Egyházmegyei Közlöny, 1897. január 1. 1- 2.

30 Klestenitz 2018: 139- 146.
} 
Az egyházpolitikai törvények meghozatalával szinte egy időben kezdtek el szaporodni a különböző agrárszocialista mozgalmak is az Alföld területén, melyek mind a klérus tagjait, mind a szociáldemokratákat élénken foglalkoztatták. Már az MSZDP indulásakor komoly problémát okozott az új tömegpártnak, hogy nem rendelkezik átfogó agrárprogrammal, és az ország szegényparaszti rétegeit nem tudja hatékonyan megszólítani. Mindezért a párton belül hamarosan hasadás következett be. ${ }^{31} \mathrm{Az}$ Alföldön spontán szerveződő mozgalmak érintették Heves vármegye egyes részeit is, ahol kezdetben az egri szociáldemokraták is végeztek agitációs munkát, azonban a szegényparasztok megmozdulásai egyre anarchikusabb jelleget kezdtek ölteni, így az egriek idővel inkább elhatárolódtak azoktól, és a helyi iparosok megszervezésére koncentráltak. ${ }^{32}$

E tevékenységük elsőszámú fóruma a budapesti Általános Munkás Betegsegélyező és Rokkantpénztár egri fiókegylete volt, melyet a Kereskedelmi Minisztérium 1893 júliusában a többi fiókegylettel együtt megszüntetett, és helyette állami tulajdonú betegsegélyező egyleteket hozott létre. ${ }^{33}$ A pénztár átszervezése körüli indulatok, az azt követő kétes pénzügyi tevékenység, ${ }^{34}$ végül pedig a Bánffy-kormány agrárszocialista mozgalmakkal szembeni agresszív fellépése miatt a választójoggal nem rendelkező egri munkásosztály (fóként asztalosok, építőmunkások, cipészek és szabók) szervezetekbe kezdett tömörülni, melyek elsősorban mint az egyes szaklapokra csoportosan előfizető szakmai szervezetek és nem szocialista mozgalmak müködtek a '90-es évek végéig. ${ }^{35} \mathrm{E}$ szakmai szervezetek közremüködésével jött létre 1895 nyarán 25 taggal az „Egri általánosiparos munkás asztaltársaság”, mely két évvel később mint Egri Munkásönképző Egylet müködött tovább. ${ }^{36}$

A világi és egyházi hatalom által kifejtett szocialista ellenes intézkedések miatt megrekedt a földet foglaló és birtokokra betörő agrászocialistákkal azonosított szociáldemokraták aktív politikai tevékenysége, így azok a már említett önképző egyletbe és a szakmai szerezetekbe szorultak vissza. A fellendülés csak a századfordulón vette kezdetét, amikor már nem az alacsony bérezésű egri kisiparosok, hanem az érseki nyomda dolgozói fogtak szervezkedésbe. A szakképzett, sokszor idegen nyelveket is beszélő, viszonylag jól fizetett nyomdai munkások szakegylete 1900 februárjában jött létre Vályi István vezetésével, aki 1902-ben a szociáldemokraták budapesti küldöttével való kapcsolatfelvétel után kapott utasítást arra, hogy szervezze meg az egri szakmunkások politikai szervezeteit, hogy azok a MSZDP vidéki hálózatába tudjanak integrálódni. ${ }^{37}$

\footnotetext{
31 Varga 1999: 98- 99.

32 Eger, 1893. január 20.

33 Népszava, 1893. szeptember 22. 4- 5.

34 Új Népszava, 1895. szeptember 26.

35 Misóczki 1983: 20

36 Népszava, 1895. augusztus 23. 5., A magyar munkásmozgalom történetének válogatott dokumentumai II. 354

37 Kelemen Bertalan: Régi dolgok. Igazság, 1947. április- június
} 
Egy évvel később létrejött az MSZDP megyei szervezete, mely kezdetben jóformán csak Egerben volt aktív, mivel a falvakban Várkonyi István Független Szocialista Pártjának lecsengése után a Mezőfi Vilmos vezette Újjászervezett Szociáldemokrata Párt örvendett nagyobb népszerüségnek, mely a rossz termés és az agrármunkások bérezése miatt kitörő aratósztrájkokat ismét sikeresen meg tudta lovagolni. ${ }^{38} \mathrm{Az}$ aratósztrájkokat követően a falvak lakói közül egyre többen választották inkább a kivándorlást, míg Egerben a szervezett munkások 1904-től közösen ünnepelték március 15-ét, nem sokkal később pedig az eddig igénybe vett éttermek és kávézók helyett saját munkásotthon állt rendelkezésükre, mely 1910-ben a Hevesvármegyei Takarékpénztár tízezer koronás hitelének köszönhetően egy sokkal tágasabb épületbe költözött. A fenntartási költségeket és az épületen lévő jelzálogot azonban nem tudták kigazdálkodni, ezért 1914-ben elárverezték az épületet. ${ }^{39}$ Ennek ellenére az első világháborút megelőző egy-másfél évtized az egri szocialista mozgalom politikai és mozgalmi szempontból is egyik legaktívabb időszaka. A politikai válság kibontakozásával szinkronban 1905től gyakorivá váltak a sztrájkok és bérharcok, a világháborút megelőző években pedig e gazdasági-szociális követelések mellett már a választójogi harc kapott nagyobb szerepet. ${ }^{40}$

Szintén ebben az időszakban került sor arra, hogy a szocializmus terjedése elött értetlenül álló, vagy az iránt elméleti érdeklődést mutató egyházi személyek végképp szembe kerültek a baloldali munkásmozgalommal, és igyekeztek megszervezni saját, konzervatív eszmeiségű szervezeteiket. Az egri papságtól sosem állt távolt a szociális kérdés. Az érseki nyomdában dolgozó egykori '48-as honvéd, Tóth István által életre hívott Katolikus Legényegylet a századfordulón már több évtizedes egyesület volt a városban. Az elszegényedés által fenyegetett fiatal iparostanoncok a legényegyletet követően mesterségük birtokában tagjai lehettek a Keresztény Iparoskörnek, mely már presztízsértékkel is bírt a város mikrotársadalmán belül. Az egri papság szociálisan aktív tagjai személyesen is részt vettek ezen egyesületek életében (A legényegylet elnöki posztját például mindig valamely egyházi személy töltötte be, míg a konkrét ügyeket intéző alelnökség feladatait világi személy látta el). ${ }^{41}$ Társadalmi nevelő munkájuk az irodalmi és pasztorális tevékenységen, valamint templomi prédikációkon túl szakkörök, kirándulások, ifjúsági színház és sok más egyéb program szervezésében, azaz az iparostanoncok vallásos tanításában és nevelésében nyilvánult meg. XIII. Leó pápa Rerum Novarum, de különösképpen a magyarországi katolikusokat társadalmi önszerveződésre felszólító Constanti Hungarorum kezdetű enciklikájától kezdve a klérus tagjai a nevelő munka mellett már a közügyek felé is nyitottá váltak. ${ }^{42}$ Leó pápa az egyházpolitikai küzdelmek közepette kiadott 1893-as enciklikájának egyik

\footnotetext{
38 Nagy 1956: 39- 40.

39 Uo. 40., 56- 57.

40 Uo. 43- 54.

${ }^{41}$ Az egri Katholikus Legényegylet müködése az 1860-dik év szeptember 8-án tartott ünnepélyes megnyitásától 1861-ik év végéig. Eger, 1862. 1-5. Szecskó 1992/1: 6- 21.

42 Gergely 1982: 312- 315.
} 
kulcsmondata (Scriptus scripta opponenda - Írásokkal szemben írást állítani) ${ }^{43}$ folytán az egri papok irodalmi tevékenységében egyre sürübben voltak jelen társadalmi kérdések, azonban a századforduló szocialista mozgalmainak hatására Egerben is egyre inkább a gyakorlati tevékenységben látták a munkáskérdés megoldását.

Ilyen volt az egri iparoscsaládba született, majd 1901-ben pappá szentelt Nagy János, aki 1903-ban, kétéves kihagyást követően került vissza Egerbe. Már korábban élénken érdeklődött a szociális kérdések iránt, Egerbe történő visszatérése után pedig aktívan bekapcsolódott a már említett vallásos mozgalmakba, valamint 1906-ban létrehozta az Egri Keresztényszocziális Egyesületet, a belpolitikai válság során pedig sikeresen tudta építeni mozgalmát a szocialisták kárára. ${ }^{44}$ Aktív közbenjárásának köszönhetően 1910-re elkészült a Legényegylet kibővített székháza, melyben valamennyi keresztényszociálisés munkásegyesület helyet kapott. ${ }^{45}$

Ez egri munkásmozgalom előbbiekben bemutatott vázlatos történetében a vallásos keresztényszocialista és baloldali szociáldemokrata tábor tevékenysége többször keresztezte egymást, a köztüklévő viszony pedig az 1890 -es évek közepétől meglehetősen elmérgesedett. Tanulmányunk következő részében a köztük feszülő ellentét konkrét megnyilvánulásait mutatjuk be.

\section{A szocialista munkásmozgalom konfliktusai és kapcsolatai a Katolikus Egyházzal}

A modern baloldali antiklerikalizmus gyökerei a felvilágosodás racionalizmusában keresendők, mely azt követően a 19. század derekán Marx (Hegelből és Feuebachból táplálkozó) materialista filozófiája nyomán kapott új erőre, ami ekkor egybe esett Európában a szekuláris polgári államformák, törvények és szokások elterjedésével. Később (főleg Engels és a II. Internacionálé tevékenységének köszönhetően) a baloldali szocialista mozgalmak jellemzőjévé is vált. ${ }^{46}$

A fennmaradt források szerint Egerben a Szabó Sándor vezette mozgalom kialakulásával egy időben jelent meg a vallás, illetve vallástalanság kérdése a nyilvánosság előtt. A betegsegélyező pénztár helyi fiókjának megalakulásakor Szabó szerette volna bevonni a szervezkedésbe az érseki nyomda dolgozóit is. Külön találkozót is szervezett az Általános Munkásegyletet vezető Ihrlinger Antal és a nyomdában ügyvezetőként tevékenykedő Tóth István között, melyet Tóth végül visszautasított, miután a Szabótól

\footnotetext{
43 Balogh-Gergely 1993: 120.

44 Nagy 1979: 281- 285.

45 Szecskó 1992/2: 32- 33.

46 Adriányi 2005: 16-17.
} 
kapott Munkás-Heti Krónika egyik számát alaposabban áttanulmányozta. ${ }^{47} \mathrm{Az}$ érseki nyomda dolgozói így kimaradtak a szerveződésből. A betegsegélyező pénztár alakulógyülésén szintén szóba került a vallás kérdése, mivel a pénztárt alapokmányában, mint „humanistikus intézményt” tüntették fel az alapítók, mely ellen az egyik jelenlévő iparos emelt szót mondván, hogy ilyen intézmény „... magával a megváltóval jött létre”, továbbá hogy „ily intézetre szükség Egerben nincs, mivel több féle betegápoldák léteznek, de azonban ennek az egyletnek más célja van, az pedig a társadalom felforgatása, a vagyon veszélyeztetése stb." A hozzászólót végül mint az egyesülés kerékkötőjét torkolták le jelenlévő társai. ${ }^{48}$ Később a pesti szabók ünnepélyes zászlószentelésre hívták egri kollégáikat, ${ }^{49}$ melyet Szabó a Munkás-Heti Krónika lapjain utasított vissza, mondván „... az általános munkásegyesüléshez tartozók minden felekezetiségtől nem csak tartózkodnak, hanem azt elítélik, mert az emberek közt visszavonást szül, s elörehaladástegyetértést zavarja" ${ }^{50}$ Később az 1880- '81-es népszámlálás megkezdése előtt nyilvánosan szólította fel elvtársait, hogy az adatfelvételkor vallják felekezetnélkülinek magukat. ${ }^{51}$ Szabó a vallásban és a felekezetiségben a hazai munkások egyesülésének legnagyobb akadályát látta, de emellett hitet tett a szocializmus profán megváltástana mellett is: „vallásunk a Szeretet, erkölcsünk a Munka (...) egyedüli törekvésünk az összemberiség müvelödését a lehetö legmagasabb fokra emelve (...) a társadalomnak oly alakot adni, melyben Szabadság, Egyenlöség, Testvériség nem sallangos frázisokba, de tényekbe kell hogy nyilvánuljanak". ${ }^{2}$

Szabó vallásellenes megnyilvánulásai nem maradtak reakció nélkül. Az ateizmus a korszakban nem volt sürün használt fogalom, azonban a felekezetnélküliség propagálása az adminisztráció folytán veszélyt jelentett az egyházak számára a polgári állammal szemben. Nem besszélve arról, hogy a szocializmus, mely az egyházak nélküli megváltást hirdette, alapjaiban kezdte ki a katolikus tanításokat. Épp ezért az Irodalmi Egyesület 1887-ben pályázatot hirdetetett, melynek az volt a célja, „hogy a jelenkori szocializmus keletkezése és veszélyeinek kifejtésével bizonyittassék be, hogy a szociális bajok az anyaszentegyház nélkül hatályosan nem orvosolhatók". A pályázatot Ambrus István szemináriumi prefektus és teológiai tanár „A Socialismus” című munkája nyerte, ${ }^{53}$ melyben Marx és Engels, valamint a szocialista elődök (Saint Simon, Fourier stb.) bemutatásán túl megfogalmazta a katolikus egyház álláspontját is a társadalmi kérdésekkel szemben, miszerint nélkülöző munkásra „a földön nem mosolyog feléje mennyország, de ez utóbbit ne is a földön, hanem a síron túl keresse". ${ }^{54}$

\footnotetext{
${ }^{47}$ Munkás-Heti Krónika, 1876. május 14. 3.

48 Uo.

49 Munkás-Heti Krónika 1876. július 30. 4.

50 Munkás-Heti Krónika 1876. július 23. 4.

51 Népszava, 1881. január 9. 2.

52 Munkás-Heti Krónika, 1877. június 24. 3.

53 Koncz 1892: 2. Eger, 1888. május 15. 155.

54 Ambrus 1889: 214.
} 
Az egyháziak „ébredezésével” egy időben Szabó Sándor és szerveződő mozgalma kereste a kapcsolatokat a befolyásos helyi politikusokkal, főként Csiky Sándorral, ezért feltehetőleg nem akart komolyabban konfrontálódni a függetlenségi politikusok egy részével is jó kapcsolatot ápoló katolikus papsággal. Az első egri május elsejék megünneplésekor az egyházhoz közeli Eger viszont gúnyos szavakkal illette a munkások szerveződését, ${ }^{55}$ később pedig az MSZDP 1890-es alakulógyülésén Szabó Sándor indítványozta, hogy az elvi nyilatkozatba kerüljön be az elemi iskolák államosításának és a hitoktatás beszüntetésének szándéka. ${ }^{56} \mathrm{Az}$ egyházi sajtó sem tétlenkedett. Az 1893-as év folyamán az Egri Egyházmegyei Közlöny cikksorozatot közölt, melyben a „társadalmi kérdéssel”, valamint a szabadgondolkozás és polgárosodás témáival foglalkoztak. ${ }^{57}$ Kifejezetten a szocializmusról azonban csak 1895-től értekezett a helyi katolikus sajtó. A „Jelszavak” című cikkben például a szociális kérdést a liberalizmussal, és annak törekvéseivel azonosították, „melyek mögött az ismert $s$ az egész világot istápoló és átölelő nagy és hatalmas cég rejtözik, a „szabadkőmüvesség”. ${ }^{8}$ Ugyanakkor egy másik helyen elismerték, hogy „a vajúdó XX-ik századnak talán végzetes kovászát a szociális kérdés fogja alkotni" ${ }^{59}$ A sajtó hasábjain először Kerekes Arvéd ismerte fel igazán az ipari átalakulás társadalmi és gazdasági következményeit. „A munkáskérdés” című írásában elítélte a munkásokat hergelő demagóg szónokokat, azonban elismerte a kapitalizmus negatívumait, azokat az emberi gyarló természetre vezette vissza: „a jelen idő társadalmi félszegsége, a szegénység nyomora és elnyomása, a gazdagok érzéketlensége és féktelensége nagyrészt elöidézöik a szenvedélyek túlkapásainak" ${ }^{60}$ Ezzel egy időben a szerkesztők „keresztény szociális szövetkezetek” alapítására szólították fel olvasóikat, melyet azzal indokoltak, hogy csakis az egyházpolitikai reformok miatt a társadalmi életből kiszorult egyház képes arra, hogy a „nyomorral küzdő osztályt sorsának javítása által a gazdagokkal kibékítsék" ${ }^{61}$

Ugyan a szocialistaellenes reakció csírái már egész korán megjelentek, az 1890es évek közepén a katolikus közvélemény számára még az egyházpolitikai reformok miatti sérelmek gyógyítása volt elsődleges, ezért a főpapsággal ellenben a katolikus arisztokrácia és egyes papi személyek is szimpátiával viszonyultak az 1895 januárjában zászlót bontó Katolikus Néppárt felé. ${ }^{62}$ Az Alföldről a megye irányába terjedő, egyre kaotikusabbá váló szegényparaszti megmozdulások azonban a következő években egyre jobban a szociális problémák felé irányították a klérus figyelmét. A kiegyezés 30.

\footnotetext{
55 Eger, 1890. május 6. 142. Eger, 1891. április 7. 113. Ezekben az írásokban a május 1-jei munkaszüneti napért való törekvéseket a munkások léhaságával és lustaságával magyarázták.

56 Népszava, 1890. december 21. 2.

57 Ehhez lásd többek között az Egri Egyházmegyei Közlöny 1893-as évfolyamának január 1. és október 1. közötti számait. A társadalmi kérdésekről a főszerkesztő Böhm István, a szabadgondolkodásról Kerekes Arvéd, míg a polgárosodásról Pigay István írt.

58 Egri Egyházmegyei Közlöny, 1895. március 16. 42.

59 Egri Egyházmegyei Közlöny, 1895. június 16. 89.

60 Egri Egyházmegyei Közlöny, 1895. november 21. 162.

61 Uo. 164.

62 Gergely 1989: 56.
} 
évfordulóján a főrendiházban rendezett ünnepélyes ülésen Samassa József egri érsek, amellett hogy hitet tett a dualizmus intézményrendszere mellett, kifejtette, hogy az elmúlt évek gazdasági fejlődése sosem látott erkölcsi romlást hozott, mivel az uralkodó osztályok visszaélnek kiváltságos helyzetükkel, a választási rendszer igazságtalansága és a megélhetési nehézségek miatt pedig a jelenlévők, elsősorban a katolikus föpapok dolga lenne a munkáskérdés felkarolása. Ahogy ő fogalmazott: „... a munkáskérdésnek nem csak anyagi, de föleg vallás erkölcsi oldala van". ${ }^{3}$

Az egyházmegyét vezető fópásztor megnyilvánulása iránymutatásként szolgált az egri klérus számára. A helyi katolikus sajtó cikkeiben (legyen szó tanügyi, közegészségügyi, kulturális, vagy épp történelemi témájúról) a társadalomról immár osztályszempontok szerint is értekeztek, elismerve ezzel a szélsőséges méreteket öltő egyenlőtlenségeket. A világi elit az irodalmi tevékenység helyett azonban hatásosabban akart fellépni a baloldali mozgalmak ellen. Miután az egri húspiacon egy csoport kihirdette a szociáldemokrata párt megyei szervezetének megalakulását, ${ }^{64}$ és az agrárszocialista megmozdulások is soha nem látott méreteket öltöttek az országban, a vármegye törvényhatósági bizottságán belül az alispán vezetésével megalakult „Heves Vármegye Antiszocialista Bizottsága” 14 taggal, akik közül négyen (Malatinszky György, Párvy Sándor, Szmida Viktor és Zalár József) az egyházmegye papjai is voltak. ${ }^{65}$ A bizottság föleg az agrárszocialisták és a Független Szocialista Párt terjeszkedése ellen bontott zászlót, azonban az egri iparosokra támaszkodó helyi szociáldemokratákat is velük azonosította. ${ }^{66} \mathrm{~A}$ bizottság jegyzőkönyvei szerint az egyházi tagok fokozottabb megértést mutattak a társadalmi mozgalmak iránt, a Bánffy-kormány „erőskéz politikája” pedig valamennyi bizottsági tag számára ellenszenves volt a későbbiekben. ${ }^{67}$

Az alföldi lázadások eredményeként a „rabszolgatörtvényként” elhíresült 1898. II. „a munkaadók és mezőgazdasági munkások közötti jogviszony szabályozásáról szóló törvénycikk" szigorú büntetést határozott meg a lázításért, és sztrájkok szervezéséért. ${ }^{68} \mathrm{~A}$ törvény megjelenését követően többen irodalmi formában próbálták azt népszerüsíteni, melyekből néhányat a földmüvelésügyi minisztérium az egri érsekségre, majd egyes plébániákra is elküldött. ${ }^{69}$ Ezzel egy időben az Egri Egyházmegyei Közlöny hasábjain először szólították fel az egyházmegye papjait és tanítóit, hogy ne csak szervezkedjenek

${ }^{63}$ Egri Érseki Levéltár, Érseki Körlevelek 1897/V.783.sz. „Nagyböjti főpásztori levél”, ill. Egri Egyházmegyei Közlöny 1897. április 16. 73.

${ }^{64}$ Hevesvármegyei Hírlapok, 1897. június 13. 1- 2. A cikkből nem derül ki az alapítók személye és a pártszervezet működésének a későbbiekben sem lelni nyomát.

${ }^{65}$ A máshol „Szocialista Ellenes Bizottságként” nevezett csoport jegyzőkönyvei az MNL HML HVTB, IV-402/c/35-ben találhatók. A tagok névsora a január 24-ei ülés jegyzőkönyvéből származik. Bővebben lásd: Misóczki 1983: 40- 46.

${ }^{66}$ Egerben csak a Maklári hóstyán élő, főként földműveléssel foglalkozó helyiek között indult meg valamiféle laza szervezkedés. Egri Híradó, 1898. február 28. 5-7., 1898. április 13. 3.

67 Uo.

${ }^{68}$ https://net.jogtar.hu/getpdf?docid=89800002.TV\&targetdate $=\&$ printTitle $=1898 .+\% \mathrm{C} 3 \% A 9 v i+\mathrm{II} .+\mathrm{t} \%$ C3\%B6rv\%C3\%A9nycikk\&referer=1000ev (Letöltve: 2020.05.28.)

${ }^{69}$ Misóczki 1983: 53- 54. Ilyen volt Szabó Tamás „Az új munkástörvény rigmusokban”; Nagy Sándor „Gazdasági munkások törvénykönyve”, valamint „Sebestyén diák” „Dózsa György, vagy a parasztláza- 
és prédikáljanak a társadalom körében, hanem vegyék fel a harcot a szocialista eszmék ellen, mondván „... a szívekben nem lesz békesség, míg e gonosz vendég (azaz a szocialisták-M.D.) ott van. Ránk papokra vár e részben szent kötelesség. Bírjuk rá képviselőinket, hogy a baj ellen emeljék fel az ország színe előtt szavukat, kivánják a bujtogatók szigorú megbüntetését" ${ }^{70}$ Azaz a papság immár a politika porondjára lépett katolikus politikusokban látta az esélyt a szintén politizáló szocialisták és szociáldemokraták visszaszorítására. Nem sokkal később jelent meg az érseki nyomda jóvoltából a „Krisztus keresztje és a vörös szocializmus” címü könyvecske, melyben az egykori hitvitákhoz hasonlóan a szocialista téziseket keresztény valláson alapuló antitézisekkel cáfolták meg. ${ }^{71}$

A szocialisták is reagáltak az egyház felől jött támadásokra. Retorikájukban a katolikus egyház, mint a hamis keresztények és a népen nyerészkedő korrupt papok gyülekezete jelent meg, míg saját magukat a szereteten és testvériségen alapuló krisztusi tanítások hordozóiként tüntették fel. ${ }^{72}$ A kor hétköznapi embereinek egy része (kik életüket még a vallási tradícióktól telítve élték, bár már szembesültek a modernkor sürüsödő szociális problémáival) bizonyára elgondolkodhattak mindezen. Samassa érsek ezért több körlevelében is kifejtette, hogy a szocialisták „azzal a mondhatni szentségtörö tisztelettel becstelenitik meg Krisztust, hogy erkölcsi tanait a szocialismus és communismus végzetes elveinek igazolására ferditik el".73

Érdekes módon a századforduló szocialista mozgalma pont az érsekség szárnyai alatt kapott új erőre. Az 1898 óta a Lyceumi nyomdában dolgozó Vályi István és nyomdász munkatársaitól induló mozgalom az 1905- '6-os zürzavaros időszakig kerülte a konfrontációt a klérussal. Ez utóbbi azonban továbbra is felemelte hangját a szocialista tanok ellen.

Az 1900-as első Katolikus Nagygyüléstől kezdve a katolikus tömegmozgalmak virágzásnak indultak. Az 1901-es egyetemi kereszt-mozgalom nyomán létrejövő Szent Imre Kört, valamint a II. Katolikus Nagygyülésen létrejövő Magyarországi Katolikus Egyesületek Országos Szövetséget, továbbá e katolikus tömegszervezeteket „eszmeileg irányító és szervezetileg összefogó" Szent István Társulatot követően megjelentek az első kifejezetten keresztényszocialista egyesületek is. Ezek a nyugati előzmények után nagyjából egy évtizedes késéssel Magyarországon is megjelenő szervezetek már a baloldali munkásmozgalommal szemben határozták meg magukat. ${ }^{74}$

dás 1514-ben" melyben a szerző az egykori parasztvezér tragédiájára próbálta felhívni a lázadásokban résztvevők figyelmét.

${ }^{70}$ Egri Egyházmegyei Közlöny 1898.február 16.30.

${ }^{71}$ Dvoreczky János (szerk.): Krisztus keresztje és a vörös szocializmus. Érseki Lyceumi Könyvnyomda, 1898.

72 Többek között: Népszava, 1902. július 15. 1- 2. „Sokan mondták és sokan mondják ma is, hogy a szoczializmus nem egyéb, mint a kereszténységnek uj formája, befejezése. A szoczializmus a való élet intézményének gyökeres megváltoztatásában megteremti az alapot azon erkölcs számára, amelyet Krisztus csupán a lelkek megváltoztatásával akart meghonosítani e földön.”

${ }^{73}$ EÉL. Érseki Körlevelek 1899/XIII.5532.sz. 13.

${ }^{74}$ Gergely 1977: 16- 18. 
Az olyan tekintélyes egyházi-közéleti személyiségek, mint Giesswein Sándor, Ernszt Sándor, vagy (az egyébként anyai ágról Samassa érsekkel rokoni viszonyban álló ${ }^{75}$ ) Prohászka Ottokár szellemi nyomdokain fejlődő keresztényszocialista mozgalmak Egerben is kifejtették hatásukat. Miután Nagy János kétéves dévaványai szolgálatát követően 1903-ban visszatért Egerbe, rögtön bekapcsolódott a város keresztény munkásszervezeteinek felrázásába. ${ }^{76}$ Emellett olyan rövid, olvasmányos és antiszemita nézőpontokat sem mellőző írásokkal hívta fel magára a figyelmet, mint a „Mit ígér és mint ad a szociáldemokrácia”, valamint „A Szociáldemokrácia tükre” című kis füzetek. ${ }^{77}$

Egri müködése alatt sokszor személyesen próbálta a helyi munkásokat az irányítása alatt álló szervezetekbe toborozni. A belpolitikai válsággal egy időben zajló sztrájkok közepette a Népszava 1906-os „Lélekkufárok” című cikke azzal támadta meg Nagy Jánost, hogy felbujtására kizárták azokat az egri építőipari dolgozókat a munkából, akik nem voltak hajlandók belépni a frissen létrehozott Keresztényszocziális Egyesületbe. A munkáltatók a cikk szerint még többet is fizettek volna a belépésért dolgozóiknak, akik közül azonban a legtöbben nem éltek a lehetőséggel ${ }^{78} \mathrm{~A}$ cikk hatására a Keresztény Iparoskör 1906. május 9-én tüntetést szervezett, melyen valamennyi keresztény egyesület képviseltette magát. ${ }^{79}$ A cikk hatására a Vályi vezette sztrájkoló szociáldemokrata szervezett munkások az egri elit csoportok számára veszélyesekké, míg a szélesebb vallásos közvélemény számára ellenszenvessé váltak. Vályit kollégájával együtt az érseki nyomdából is eltanácsolták, ezért 1908-ig Kassán élt családjával. ${ }^{80}$ Miután visszatért Egerbe, immár nem sztrájkokkal és bérharcokkal szervezte mozgalmát, hanem igyekezett bevonni azt az országosan szerveződő választójogi mozgalmakba, bár a választójog kérdésével kapcsolatban a helyi értelmiséghez hasonlóan a papság sem volt közömbös. ${ }^{81}$

Az érsekség eszmei és anyagi támogatása, valamint a katolikus egriek szimpátiája miatt a keresztényszocialista mozgalom helyzeti előnybe került. Nagy János társadalmi szervező munkájának, valamint egyre növekvő befolyásának köszönhetően a Katolikus Legényegylet épületét kibővítették, így az az első világháborút megelőző pár évben a helyi keresztényszocializmus központjaként is funkcionált, ahol tanoncinternátus, valamint egy rövid ideig munkásgimnázium is müködött. ${ }^{82} \mathrm{Az}$ épület ünnepi zászlószentelésén a későbbi érsek, Szmrecsányi Lajos a baloldali munkásszervezeteket

75 Gergely 1994: 16.

76 Szecskó 1992/2: 32.

77 Nagy János: Mit ígér és mit ad a szociáldemokrácia? Szent-István-Társulat. 1903. ill. Uő: A szociáldemokrácia tükre. Szent-István-Társulat. 1911.

78 Népszava, 1906. április 27. 8- 9.

79 Szecskó 1992/1: $42-43$.

80 Csiffáry 1983: 245- 246. Szintén eltanácsolt kollégája az 1919-ben kommunista tevékenységet folytató Németi Lajos (szül. Neszvadba) édesapja, az egyébként szocialistának nem mondható Neszvadba Gyula volt. Németiről bővebben lásd: Tóth 2019: 13.

81 Ezzel kapcsolatban érdemes kiemelni Halászy Caesar munkásságát, melyről bővebben: Pap 2011: 6876., ill. Halászy 1908: 3- 39.

82 Szecskó 1992/1: 13. 
mint ateista, felforgató, nemzetellenes elemeket minősítette beszédében: „Hiába hirdet más tanokat a gögös emberi elme (...) hiába mondja, hogy a társadalmi érdekharcokban nincs szava a vallásnak (...) A téves tanok már megrontották a közéletet, megmételyezték a társadalmat; nagyon itt van tehát az ideje annak, hogy a becsületes lelkek, a jó hazafiak e zászló köré csoportosuljanak, ezt kövessék. Az emberi gög (...) gyülöletet hirdet a szeretet helyett és forradalommal akarja kiegyenlíteni a társadalmi ellentéteket" ${ }^{83}$ Emellett hangsúlyozta a munkáskérdés keresztényi erkölccsel és szeretettel való megoldásának fontosságát, és a vallástalan mozgalmak elleni harc programját is felvázolta: „Közre kell müködnie majd e háznak is abban a harcban, amely az ipari munkásság sorsának javitása érdekében megindult és föltartóztathatlan módon hatol elöre (...) E munkára most annál nagyobb a szükség, mert a mester és munkás között elszakadt az abrosz. A közönség, a munkaadó és munkás között megszakadt a szeretetteljes kapcsolat" ${ }^{84}$

A vallásos szervezetek elöljárói többször intették arra a csoportok tagjait, hogy kerüljék a világi szervezeteket, mivel az egyház szerint „derék iparosok, hazaszerető munkáspolgárok csak akkor lehetnek, ha egyszersmind vallásosak is". ${ }^{85}$ Nagy János 1912ben már azoknak a tagoknak az eltávolítását követelte az egyletekböl, akik megjelentek a szociáldemokrata gyüléseken. Később az említett tagok csak figyelmeztetést vagy megrovást kaptak. Érdekes viszont, hogy a világháború kitörésének évére már egyetlen ács vagy kőmüves tagja sem volt a keresztény egyleteknek. Szinte mindannyian a szakszervezetekbe kapcsolódtak be. ${ }^{86}$

\section{Összefoglalás}

Az egri kispolgári csoportok egy jelentős része fokozatosan szegényedett el, és ezzel együtt vesztette el gazdasági súlyát, amiből fakadóan jellemző volt rájuk egyfajta kapitalizmusellenesség és szociális frusztráció. A századfordulót megelőzően a köztudatban elterjedő szociális ideológiák és programok, valamint maga a munkáskérdés tünetei Egerben is éreztették hatásukat, aminek köszönhetően az egyházi szociálpolitika homlokterébe kerültek a leszakadó rétegek. Ez azonban nem gátolta meg, hogy a megélhetésükben veszélyeztetetté váló mesterek és kétséges jövőbeli egzisztenciájuk miatt elkeseredett tanoncok egy része a szociáldemokrata mozgalomhoz is csatlakozzon. Hasonló volt a helyzet a filoxérát elszenvedő szőlőbirtokosok esetében is. E csoportokat az egyház valláserkölcsi alapon, míg a külföldi és nagyvárosi példákból kiinduló szociáldemokraták az egyházakat mellőzve, és sokszor a helyiek vallásos érzületét

\footnotetext{
${ }^{83}$ Eger, 1910. szeptember 14. 3.

${ }^{84}$ Uo.

${ }^{85}$ Eger, 1910. szeptember 14. 3- 4.

${ }^{86}$ Kolacskovszky 1969: 12.
} 
figyelmen kívül hagyva próbálták felkarolni. A munkásmozgalom e két szárnyának viszonya meglehetősen hullámzó volt. A sajtóban és értekezésekben megjelenő elméleti kritikáktól kezdve a tömegpolitizálásig, számos eltérő módon reflektáltak egymás tevékenységére, azonban a kettejük közti elvi ellentétet sem a dualizmus időszakában, sem pedig később nem sikerült feloldani.

A világháborúsévekalatt végül az egri munkásmozgalom jobb és bal szárnya is megtört. Mindkét irányzat elsősorban a katonakorú, iparban dolgozó népességre támaszkodott. Az idősebb munkások, akiket a frontszolgálat már nem érintett, a politikai szerveződés helyett a háborús hátország mindennapi nehézségeivel voltak elfoglalva. A háborút követő forradalmi időszak a szocialistáknak, míg a két világháború közti periódus az egykori keresztényszocialista mozgalmakból kifejlődő szervezeteknek kedvezett. Az 1945 utáni történetírás azonban nem kezelte elég árnyaltan a hazai munkásmozgalom történetét. Annak irányzatai közt csak elvétve tett különbséget, és elsősorban a radikális irányzatok tevékenységét hangsúlyozta. Reméljük e rövid tanulmány, ha csak szerény keretek között is, de tudta árnyalni ezt az egyoldalú képet.

\section{Felhasznált források}

Eger, 1888. május 15.

Eger, 1890. május 6.

Eger, 1891. április 7.

Eger, 1893. január 20.

Eger, 1910. szeptember 14.

Eger, 1914.március 4.

Egri Egyházmegyei Közlöny, 1895. március 16.

Egri Egyházmegyei Közlöny, 1895. június 16.

Egri Egyházmegyei Közlöny, 1895. november 21.

Egri Egyházmegyei Közlöny, 1897. január 1.

Egri Egyházmegyei Közlöny 1898. február 16.

Egri Híradó, 1898. február 28.

Egri Hiradó, 1898. április 13.

EÉL. Érseki Körlevelek 1899/XIII.5532.sz. 13.

EÉL, Érseki Körlevelek 1897/V.783.sz. 
Hevesvármegyei Hírlapok, 1897. június 13.

MNL HML HVTB, IV-402/c/35

Munkás-Heti Krónika, 1876. május 14.

Munkás-Heti Krónika 1876. július 23.

Munkás-Heti Krónika 1876. július 30.

Munkás-Heti Krónika, 1877. június 24.

Munkás-Heti Krónika 1879. június 1.

Népszava, 1880. április 11.

Népszava, 1880. június 27.

Népszava, 1880. július 11.

Népszava, 1881. január 9.

Népszava, 1890. december 21.

Népszava, 1893. szeptember 22.

Népszava, 1895. augusztus 23.

Népszava, 1902. július 15.

Népszava, 1906. április 27.

Új Népszava, 1895. szeptember 26.

\section{Felhasznált szakirodalom}

Adriányi Gábor 2005: A Katolikus Egyház története a XX. században Kelet-, Középkelet és Dél-Európában. Budapest.

A magyar munkásmozgalom történetének válogatott dokumentumai. I kötet. A magyar munkásmozgalom kialakulása.

A magyar munkásmozgalom történetének válogatott dokumentumai. II. kötet. A magyar munkásmozgalom az imperializmusra való átmenet időszakában. 18901900.

Ambrus István 1889: A Socialismus. Eger.

Ambrus László 2017: Filoxéravész a bükkaljai borvidéken. In: Ballabás Dániel (szerk.): Mozaikok a 18-20. századi magyar és egyetemes történelemböl. Eger. 7-16. 
Az egri Katholikus Legényegylet müködése az 1860-dik év szeptember 8-án tartott ünnepélyes megnyitásától 1861-ik év végéig. Eger, 1862.

Balogh Margit- Gergely Jenő 1993: Egyházak az újkori Magyarországon 1790-1992. Kronológia. Budapest.

Bodovics Éva Judit 2017: Építő áradat. Városfejlődés az árvíz segítségével Eger és Miskolc példáján keresztül. Urbs - Magyar Várostörténeti Évkönyv 10- 11. Budapest. 71 -99.

Csesznokné Kukucska Katalin 2007: Heves vármegye (1867- 1912) lakosságát súlytó legnagyobb járványok: kolera, scarlatina, trachoma, és ezek demográfiai következményei. Acta Academiae Paedagogicae Agriensis Nova Series: Sectio Historiae XXXIV. 261- 269.

Csiffáry Gergely 1983: Adatok Vályi István (1875- 1942) életrajzához. Heves Megyei Propagandista 14 évf. 64. sz. Eger. 240- 255.

Csóka János 1958: Az egri dohánygyár 60 éve. (1895-1955). Az Egri Pedagógiai Főiskola Évkönyve 4. Eger. 375- 297.

Demeter Gábor 2004: A dualizmus kori Eger lassú népességnövekedésének demográfiai hátteréröl. Acta geographica ac geologica et meteorologica Debrecina 37. Debrecen. 181- 197.

Dersi Tamás 1973: A századvég katolikus sajtója. Budapest.

Gergely Jenő 1977: A keresztényszocializmus Magyarországon 1903- 1923. Budapest.

Gergely Jenő 1982: A pápaság története. Budapest.

Gergely Jenő 1989: Katolikus Egyház, magyar társadalom. Budapest.

Gergely Jenő 1994: Prohászka Ottokár „A napbaöltözött ember”. Budapest.

Gyáni Gábor- Kövér György 2006: Magyarország társadalomtörténete a reformkortól a második világháborúig. Budapest.

Halászy Caesar 1908: A választói jog. Eger.

Hanák Péter 1959: A dualizmus válságának problémái a XIX. századvégén. Történelmi Szemle 1959/1 - 2. Budapest. 37-89.

Kárbin Ákos 2018: A kultúrharc Egerben, és következményei. Az állami anyakönyvezés bevezetésének nehézségei. In: Horváth István (szerk.): Fejezetek az ezer éves Egri Egyházmegye történetéböl. Eger. 153- 166.

Klestenitz Tibor 2018: Az Egri Főegyházmegye Katolikus sajtója a dualizmus korában. In: Horváth István (szerk.): Fejezetek az ezer éves Egri Egyházmegye történetéből Eger. 139- 152

Kolacskovszky Lajos 1969: Az „őszirózsás”- forradalom és Kommün Heves megyében Visszaemlékezések. Megyei Könyvtár Füzetei 17. Eger.

Koncz Ákos 1892: Egri Egyházmegyei papok az irodalmi téren. Eger. 
Kozári József 1982: Adalékok a filoxéra-pusztításának Eger város gazdaságára gyakorolt hatásához. Acta Academiae Paedagogicae Agriensis nova series Tomus XVI. Eger. 129- 140 .

Kozáry Andrea 1999: Az egylettől a párt megalakításáig. In: Varga Lajos (szerk.): A szociáldemokrácia kézikönyve. Budapest.

Löffler Erzsébet 1984: Adatok a filoxéra egri történetéhez. In: Bodó Sándor (Szerk.): Agria 20. Az Egri Múzeum Évkönyve. Eger. 147- 164.

Misóczki Lajos 1983.: Heves megye szegényparaszti és munkásmozgalma az I. világháborúig. I. rész. (1890- 1900). Heves Megyei Propagandista 14. évf. 64.sz. Eger. 5- 93.

Misóczki Lajos 2001: A tőkés agrárfejlődés gondjai Füzesabonyban és környékén 18671945 között. In: Horváth László (szerk.): Mátrai Tanulmányok. Gyöngyös. 235- 246.

Nagy József 1956: A heves megyei munkásmozgalom kezdeti szakasza (1850-1914). Eger.

Nagy József 1978: Eger története. Budapest.

Nagy József 1979: A Heves megyei munkásság harcai az 1905- 1906-os belpolitikai válság idején. Acta Academiae Paedagogicae Agriensis Nova series, Tom. 15. Eger. 275- 293.

Nagy József 1981: Az ipari és mezőgazdasági munkásság kialakulásának körülményei Heves megyében. Heves Megyei Propagandista 12. évf. 51. sz. Eger. 16- 41.

Nagy József László é.n.: Az egri munkásmozgalom előtörténete. Hevesi Szemle 4. sz. 65- 67.

Pap József 2011: A választójog kiterjesztése körül folyó vita és az egri közélet a huszadik század elején. In: Ballabás Dániel (szerk.): Trianon 90 év távlatából. Konferenciák, mühelybeszélgetések. Eger. 60- 87.

Romsics Ignác 2005: Magyarország története a XX. században. Budapest.

Szecskó Károly 1992: A keresztényszocializmus egri úttörője: Dr. Nagy János kanonok. Honismeret 1992/1. sz. Budapest. 32- 34.

Szecskó Károly 2010: Az egri kolping család. A katolikus legényegylet története (18602010). Eger.

Szederkényi Nándor: 1893: Heves vármegye története. IV. Eger.

Szokol Réka: 2011: Kispolgárok. Fogalomtörténeti vázlat. Múltunk 56. évf. 2. sz. 104128.

Tóth Marcell 2019: Németi Lajos, a „vörös Forrest Gump” Képek, kérdések, kiegészítések, kritikák egy kommunista életrajzához. Hódmezővásárhely. 
Varga Lajos 1999: A Szociáldemokrata Párt Magyarország politikai életében (18901956). In: Varga Lajos (szerk.): A szociáldemokrácia kézikönyve. Budapest.

Veres Gábor 2011: A városfejlődés sajátosságai Egerben a 18- 19. században. Történeti Muzeológiai Szemle 11. Budapest. 101- 104.

\section{Internetes forrás}

http://ujkor.hu/content/tavaszi-viragzastol-a-munkasunnepig-majus-1-ejelentesvaltozasanak-tortenete (Letöltve: 2020. szeptember 5.)

https://net.jogtar.hu/getpdf?docid=89800002.TV\&targetdate=\&printTitle=1898.+ \%C3\%A9vi+II.+t\%C3\%B6rv\%C3\%A9nycikk\&referer=1000ev (Letöltve: 2020. szeptember 5.) 